\title{
The expectation gap in auditing
}

\author{
Saeid Jabbarzadeh Kangarluie ${ }^{a^{*}}$ and Abbas Aalizadeh ${ }^{\text {b }}$
}

\begin{abstract}
${ }^{a}$ Assistant Professor, Accounting Group, Oroumieh Branch, Islamic Azad University, Oroumieh, Iran ${ }^{b}$ PhD Student, Assistant Professor, Accounting Group, Oroumieh Branch, Islamic Azad University, Oroumieh, Iran

C H R O N I C L E

Article history:

Received December 5, 2015

Received in revised format

February 162016

Accepted June 32016

Available online

June 32016

Keywords:

Audit

Audit expectations gap

Independent auditors

Auditor Independence A B S T R A C T

There is a concern that auditors and the public may have different beliefs about the auditors' responsibilities and the messages delivered by audit reports. During the past few years, some spectacular and well-publicized corporates such as Anderson consulting collapse and the subsequent implication of the reporting auditors have emphasized on the audit expectation gap. It appears that public misperceptions represent a major reason for the legal liability crisis facing the accounting profession. The objective of this paper is to present an empirical investigation on the audit expectation gap for some privately hold firms in Iran. The population of this survey includes two groups of official auditing officials and management of some privately held firms. The results of the survey have indicated that there were some meaningful difference between management and audit group's perceptions in terms of the auditors' roles and responsibilities. However, there was no meaningful relationship between management and audit group's perceptions in terms of the auditors' independence.
\end{abstract}

\section{Introduction}

There is a concern that auditors and the public may have different beliefs about the auditors' responsibilities and the messages delivered by audit reports. During the past few years, some spectacular and well-publicized corporates such as Anderson consulting collapse and the subsequent implication of the reporting auditors have emphasized on the audit expectation gap. Chye Koh \& Woo, 1998; Gramling et al., 2004). Humphrey et al. (1992) explored the response of the accounting profession to the audit expectations gap in the United Kingdom. Munir Sidani (2007) evaluated the existence of an expectation gap between accountants and non-accountants in Lebanon. He reported that there was a gap between the auditors' understanding of their profession compared with the perceptions of others. There was also a substantial difference in perceptions of the role of the auditor in terms of fraud detection. Haniffa and Hudaib (2007) shed light into audit expectations gap, which exists within a cultural context by investigating whether or not the business and social environment influence on the perceptions of audit performance of users and auditors. Using a combination of mail questionnaires and some interviews, they disclosed the existence of a 'performance gap' in terms of the roles specified * Corresponding author

E-mail address: Jabbrzadeh.s@gmail.com (S. Jabbarzadeh Kangarluie) 
in the statutory pronouncements and those that can reasonably be expected of auditors in Saudi Arabia. The results stated the 'performance gap' could arise from four factors namely; licensing policy, recruitment process, the political and legal structure, and dominant societal values. The study also disclosed the effect of institutional and cultural settings on the audit expectations gap and reported that the inclusion of Islamic principles in auditing standards and the code of ethics reduces the expectations gap.

Salehi et al. (2009) investigated about auditor independence and audit expectation gap and reported that an independent auditor is important since the separation of ownership from the management; the independent factor is the foundation of the public accounting profession. Shaikh and Talha (2003) investigated different studies that test the extent to which international auditing boards had accomplished to reduce the expectation gap in reporting on uncertainties. This is due to the fact that there used to be a long-running controversy between the auditing profession and the community of financial statement users on the responsibilities of the auditors to the users. Lin and Chen (2004) reported from a survey that the role of public accounting had been positively recognized by Chinese audit beneficiaries and auditors, and there were increasing demands for developing the applicability of public accounting.

Chowdhury et al. (2005) investigated whether there is an audit expectations gap in the public sector between the Comptroller and Auditor General's (CAG) auditors in Bangladesh and the users of the CAG reports namely the Public Accounts Committee (PAC) of the Parliament that investigates the $\mathrm{CAG}$ audit reports and the international funding agencies (IFAs) that give external funding in the public sector in Bangladesh. Siddiqui et al. (2009) studied the impact of audit education in reducing the audit expectations gap (AEG) in Bangladesh. They reported that audit education could reduce the AEG, especially in the area of audit reliability. Their results also showed that although the introduction of accounting scandal cases in the auditing curricula could generate interest amongst the students. Adams and Evans (2004) presented a comprehensive study on accountability, completeness, credibility and the audit expectations gap.

Hassink et al. (2009) presented the findings of an empirical study on the audit expectations gap on the role of the auditor in corporate fraud cases. They evaluated the effect of a reasonableness gap and to distinguish all three elements of the expectations gap, respondents required a certain level of expertise on fraud. The study provided clear evidence of a substantial audit expectations gap in the context of fraud, both with respect to the auditor's performance as well as the auditor's formal obligations as laid down in existing standards. Garcia-Benau and Humphrey (1992) investigated the history of auditing and its regulation in Spain within the context of international developments in the accounting profession.

Gay et al. (1998) compared the perceptions of the users and preparers of financial statements to those of auditors, concerning messages conveyed by review and audit reports in terms of the capability of various groups to differentiate between the levels of assurance. In their survey, most groups claimed that review reports gave less assurance than audit reports did. In addition, users placed less responsibility on the auditor with a review, while preparers did not show any difference in the auditor's responsibility. According to Frank et al. (2001), "a large divergence in perceptions of auditors and jurors regarding their expectations of the accounting profession. However, accounting students responded in a manner very similar to practicing auditors".

\section{The proposed study}

The objective of this paper is to present an empirical investigation on the audit expectation gap on some privately hold firms in Iran. The population of this survey includes two groups of official auditing officials and management of some privately held firms. The survey was accomplished in 2013 and the 
sample size is calculated as follows,

$$
n=\frac{N \times z_{\alpha / 2}^{2} \times p \times q}{\varepsilon^{2} \times(N-1)+z_{\alpha / 2}^{2} \times p \times q},
$$

where $N$ is the population size, $p=1-q$ represents the yes/no categories, $z_{\alpha / 2}$ is CDF of normal distribution and finally $\varepsilon$ is the error term. Since we have $p=0.5, z_{\alpha / 2}=1.96$ and $N=1389$, the number of sample size is calculated as $n=318$. The survey designs a questionnaire in Likert scale consists of 32 questions where 25 questions were devoted to role and responsibities of auditors and 7 questions were dedicated to auditors' independence. Cronbach alpha has been calculated as $0.97 \%$, which is well above the minimum acceptable level. There are two hypotheses associated with the propsoed study of this paper as follows,

1. There is a meaningful difference between the auditors' roles and responsivities in management and auditors' point of view.

2. There is a meaningful difference between the auditors' independence in management and auditors' point of view.

Table 1 demonstrates the results of Kolmogorov-Smirnov test to determine whether or not the data were normally distributed.

\section{Table 1}

The results of Kolmogorov-Smirnov test

\begin{tabular}{lcccc}
\hline & \multicolumn{2}{c}{ First hypothesis: Roles and responsibilities } & \multicolumn{2}{c}{ Second hypothesis: Independence } \\
\cline { 2 - 5 } Statistics & Auditors & Managers & Auditors & Managers \\
\hline $\mathrm{N}$ & 250 & 90 & 250 & 90 \\
Mean & 3.87 & 1.63 & 3.35 & 3.37 \\
Standard deviation & 0.32 & 0.28 & 0.39 & 0.38 \\
K-S statistics & 1.197 & 0.876 & 1.353 & 1.316 \\
Sig. & 0.114 & 0.427 & 0.052 & 0.063 \\
Distribution & Normal & Normal & Normal & Normal \\
\hline
\end{tabular}

\section{The results}

In this section, we present the results of the implementation of Levene's test to see whether there is any significant difference between two groups in terms of roles and responsibilities as well as independence. Table 2 presents the results of Levene's test for the first hypothesis of the survey.

\section{Table 2}

The results of Levene's test for testing the first hypothesis

\begin{tabular}{ccccccc} 
& \multicolumn{3}{c}{ Mean } & \multicolumn{2}{c}{ Levene's test } & \\
& Managers & Auditors & F-value & P-value & P-value(t-value) & Result \\
\hline $1^{\text {st }}$ Hypothesis & 1.63 & 3.87 & 1.72 & 0.191 & 0.000 & Confirmed \\
\hline
\end{tabular}

As we can observe from the results of Table 2, there is a meaningful difference between the auditors' roles and responsivities in management and auditors' point of view. Therefore, the first hypothesis of the survey has been confirmed. Moreover, Table 3 presents details of testing the second hypothesis of the survey and we can confirm that the second hypothesis is not confirmed.

\section{Table 3}

The results of Levene's test for testing the second hypothesis

\begin{tabular}{|c|c|c|c|c|c|c|}
\hline & \multicolumn{2}{|c|}{ Mean } & \multicolumn{2}{|c|}{ Levene's test } & \multirow[b]{2}{*}{ P-value(t-value) } & \multirow[b]{2}{*}{ Result } \\
\hline & Managers & Auditors & F-value & P-value & & \\
\hline $2^{\text {nd }}$ Hypothesis & 3.37 & 3.35 & 0.004 & 0.952 & 0.661 & Not confirmed \\
\hline
\end{tabular}




\section{Conclusion}

In this paper, we have presented an empirical investigation on the audit expectation gap on some privately hold firms in Iran. The population of this survey includes two groups of official auditing officials and management of some privately held firms. The results of the survey have indicated that there were some meaningful difference between management and audit group's perceptions in terms of the auditors' roles and responsibilities. However, there was no meaningful relationship between management and audit group's perceptions in terms of the auditors' independence.

\section{Acknowledgement}

The authors would like to thank the auditing committee of Iran for cordially cooperating in accomplishment of this survey. We are also delighted for constructive comments on earlier version of this paper.

\section{References}

Adams, C. A., \& Evans, R. (2004). Accountability, completeness, credibility and the audit expectations gap. Journal of Corporate Citizenship, 14, 97-115.

Chowdhury, R. R., Innes, J., \& Kouhy, R. (2005). The public sector audit expectations gap in Bangladesh. Managerial Auditing Journal, 20(8), 893-908.

Chye Koh, H., \& Woo, E. S. (1998). The expectation gap in auditing. Managerial Auditing Journal, 13(3), 147-154.

Frank, K. E., Jordan Lowe, D., \& Smith, J. K. (2001). The expectation gap: Perceptual differences between auditors, jurors and students. Managerial Auditing Journal, 16(3), 145-150.

Garcia-Benau, M. A., \& Humphrey, C. (1992). Beyond the audit expectations gap: learning from the experiences of Britain and Spain. European Accounting Review, 1(2), 303-331.

Gay, G., Schelluch, P., \& Baines, A. (1998). Perceptions of messages conveyed by review and audit reports. Accounting, Auditing \& Accountability Journal, 11(4), 472-494.

Gramling, A. A., Maletta, M. J., Schneider, A., \& Church, B. K. (2004). The role of the internal audit function in corporate governance: A synthesis of the extant internal auditing literature and directions for future research. Journal of Accounting Literature, 23, 194.

Haniffa, R., \& Hudaib, M. (2007). Locating audit expectations gap within a cultural context: The case of Saudi Arabia. Journal of International Accounting, Auditing and Taxation, 16(2), 179-206.

Hassink, H. F., Bollen, L. H., Meuwissen, R. H., \& de Vries, M. J. (2009). Corporate fraud and the audit expectations gap: A study among business managers. Journal of International Accounting, Auditing and Taxation, 18(2), 85-100.

Humphrey, C., Moizer, P., \& Turley, S. (1992). The audit expectations gap - plus ca change, plus c'est la meme chose?. Critical Perspectives on Accounting, 3(2), 137-161.

Lin, Z. J., \& Chen, F. (2004). An empirical study of audit 'expectation gap'in the People's Republic of China. International Journal of Auditing, 8(2), 93-115.

Munir Sidani, Y. (2007). The audit expectation gap: evidence from Lebanon. Managerial Auditing Journal, 22(3), 288-302.

Salehi, M., Mansoury, A., \& Azary, Z. (2009). Audit independence and expectation gap: Empirical evidences from Iran. International Journal of Economics and Finance, 1(1), 165.

Siddiqui, J., Nasreen, T., \& Choudhury-Lema, A. (2009). The audit expectations gap and the role of audit education: the case of an emerging economy. Managerial Auditing Journal, 24(6), 564-583.

Shaikh, J. M., \& Talha, M. (2003). Credibility and expectation gap in reporting on uncertainties. Managerial auditing journal, 18(6/7), 517-529. 